\title{
Model Fitness on Emotional Intelligence, Personality Trait and Leadersip Behavior on Job Performances
}

\author{
Nurul Hudani Md Nawi ${ }^{a *}$, Ma'rof Redzuan ${ }^{a}$, Hanina Hamsan $^{\mathrm{a}}$, Ibrani Adam Asim ${ }^{\mathrm{a}}$ \\ ${ }^{a}$ Universiti Putra Malaysia, 43400 UPM Serdang, Selangor Darul Ehsan, Malaysia \\ *Corresponding author: nuruldin01@yahoo.com
}

Article history

Received :22 July 2012

Received in revised form : 2

February 2013

Accepted : 15 February 2013

\begin{abstract}
The main objective of this cross-sectional study is to determine the correlation of emotional intelligence and personality trait as well as the fitness of suggestion hypothetical model and sample data among school educator leaders in High Performance Schools (SBT). Four sets of questionnaire to measure emotional intelligence, personality trait, leadership behavior and work performance were administered to 306 (89\%) subjects in 15 SBT schools in Malaysia. The finding by the bivariate analysis using the Pearson correlation method indicates that the personality trait such as Conscientiousness $(\mathrm{r}=.552, \mathrm{p}<.05)$, Openness to experiences $(\mathrm{r}=.362, \mathrm{p}<.05)$, Extraversion $(\mathrm{r}=.505, \mathrm{p}<.05)$, Agreeableness $(\mathrm{r}=.193, \mathrm{p}<.05)$ are positively and significant correlated with overall emotional intelligence. Moreover, the results indicate an adequate fit and it obviously met the basic requirement of model fit. Therefore, the modification model is significantly improves the fit of the model to the data. On a practical note, the assessment of psychological construct in schools setting could possibly assist in enhancing the work performances in delivering huge benefits to the society especially in the educational contexts.
\end{abstract}

Keywords: Emotional intelligence; personality; leadership; work performance

\begin{abstract}
Abstrak
Kajian ini bertujuan untuk mengenal pasti hubungan bagi kecerdasan emosi dan trait personaliti dan menentukan kesepadanan model dengan data kajian dalam kalangan pemimpin pendidik di Sekolah Berprestasi Tinggi (SBT). Empat set soal selidik telah digunakan dalam kajian ini iaitu soal selidik kecerdasan emosi, trait personaliti, tingkah laku kepimpinan dan prestasi kerja dijalankan ke atas 306 (89\%) di 15 buah SBT di Malaysia. Analisis korelasi Pearson menunjukkan terdapat hubungan positif yang signifikan antara trait personaliti seperti kehematan (Conscientiousness $(\mathrm{r}=.552, \mathrm{p}<.05)$, keterbukaan (Openness to experiences ( $\mathrm{r}=.362, \mathrm{p}<.05)$, ekstraversi (Extraversion $(\mathrm{r}=.505, \mathrm{p}<.05)$, kesetujuan (Agreeableness $(\mathrm{r}=.193, \mathrm{p}<.05)$ dengan kecerdasan emosi. Di samping itu, dapatan kajian menunjukkan kesesuaian model dengan data kajian selepas modifikasi dijalankan. Dengan itu, modifikasi model mempamerkan kesesuaian yang signifikan dan fit antara model dan data kajian. Dari sudut praktikal, penggunaan pemboleh ubah psikologi berupaya meningkatkan prestasi kerja dalam memberi manfaat yang besar khususnya dalam konteks pendidikan.
\end{abstract}

Kata kunci: Kecerdasan emosi; trait personaliti; tingkah laku kepimpinan dan prestasi kerja

C) 2013 Penerbit UTM Press. All rights reserved.

\subsection{INTRODUCTION}

Nowadays, all organizations find themselves constantly facing the challenge of having to cope with the rapidly changing environment. Many organizations includes High Performance Schools (SBT) are very much influenced by turbulence associated with education globalization, changes in policy, educational innovation, liberalization technology, stakeholders expectation and etc. Therefore, there is a growing need to be sustainable in the competitive environment. The difficulty of surviving within this situation leads to various problems among student and teacher such as leads decreasing of achievement.
The Malaysian government's effort to improve the performance and achievement in the education aspect began from providing a lot of funds and facilities. To acknowledge how crucial the importance of education sector in Malaysia, the research from a very dignified sources stated that education sector in Malaysia is $60 \%$ is more important that health and security (Budget Allocation Malaysia, 2010).

However, the result of performance and academic achievement is still far and it was in the critical situation when Ministry of Higher Education (2010) reported the declination of performance from year to year among student. This finding was in line with the National Higher of Education Research Institute (IPPTN) found that decreasing in performance among the 
matriculation student up to $80 \%$. As a result, poor academic achievement among student has been associated with the failure of leaders performance as well. Therefore, it was need a new approach or model to deal and survive within this dynamic changes in environment.

Studied have shown significant differences in human behavior when there are changes in the environment (Secord \& Beckman, 1969; Piderit, 2000). Most of the changes are related to personality, emotional intelligence and many others. Other studied showed that personality and emotional intelligence are vital keys to achieve organizational goals and succeeding in change environment (Eby, Adam, Russell \& Gaby, 2000).

A proper and structured management of educator leaders in schools is vital to ensure the effectiveness of their services to the student. Thus, educator leaders should be protected against physical and emotional burden while facing organizational as well as changes in policy, communication technology and education system itself. In this changing process, educator leaders are constantly under pressure to find new and good solutions, which will preserve future competitiveness and performances.

Educator leaders should try to survive and remain competitive, they are reorganizing, reimplementing and restructuring a new approach. In other words, they constantly try to change in order to fulfill the recognization and need to be sustainable in the competitive environment to continuously improve in the face of changing conditions to enhance education system in Malaysia. These ongoing and seemingly endless efforts can put a lot of strain not only put a strain on school organization but also individual. According to Beer and Nohria (2000), 70 per cent of changes process fail is due to the lack of strategy and vision, lack of communication and trust, problem in management (leaders), resistance to change, etc. that will affect the individual work performance. The key factor for school organizations to compete and sustain themselves is personality, leadership behavior and emotional aspect towards performances.

The tolerance towards the emotional competence of educator leaders work, in turn, can be influenced by a person's characteristics such as emotional intelligence (EI), personality trait and leadership behavior on work performance (Figure 1) as a theoretical framework proposed in this study.

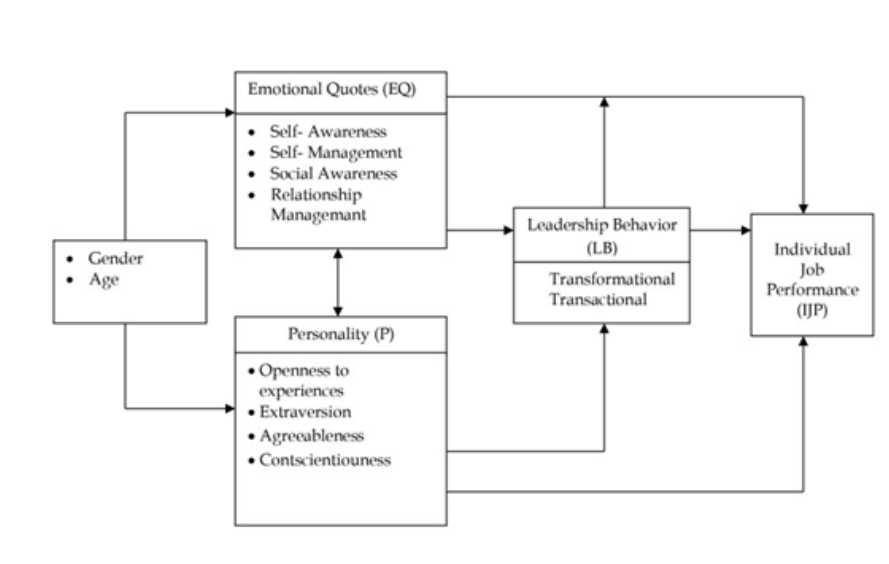

Figure 1 Theoretical framework

As the educator leaders in an organized group, like in any other profitable origination, it was required appropriate management. The need for good management comes from the fact that teacher profession can be cost-effective, but not costfree. Thus, effective management of the people in school organizations can help minimize cost, and ensuring the continuity of good service to the schools institution.

By pooling available resources, people can do much more than they can do alone. That is why there is a need to mobilize individuals in an organized manner especially in psychological construct. To manage educator leaders professionally, much like the human resource department in many organizations, the educator leaders in school institution needs professional input especially from scholars and researchers in order to understand how to produce a high quality of work performances. Additionally, when it comes to improve organizational effectiveness and enhance work performances, management from education scholars, intellectual discourse, and practitioners are beginning to emphasize the importance of a educator leader's emotional intelligence (EQ) and personality traits in order to achieve high work performance. Therefore, it is imperative study such as this is carried out to help identify these factors specifically that influence them to be engaged in organised manner to produce good quality of performances. The objective of this study are as follow 1) to determine the relationship between personality trait and emotional intelligence and 2) to determine the fitness of the suggestion model with the sample data among educator leaders.

\subsection{LITERATURE REVIEW}

\subsection{Emotional Intelligence}

The concept of emotional intelligence was firstly introduced by Salovey \& Mayer (1990) as three adaptive abilities namely the ability to: (1) appraise and express emotion, (2) regulate emotions and (3) utilize emotions in solving problems. Another definition of emotional intelligence is ability to recognize the meanings of emotions and their relationships, to reason and problem-solve on the basis of them (Mayer, Caruso \& Salovey, 2000). This model of emotional intelligence involves four branches namely 'reflectively regulating emotions', 'understanding emotions', 'assimilating emotion in thought' and 'perceiving and expressing emotion.'

Other models then offer different numbers of EI component for example the model proposed by Dulewicz and Higgs (1999) has seven components (self-awareness, emotional resilience, motivation, interpersonal sensitivity, influence, intuitiveness, and conscientiousness and integrity). On the other hand, Daniel Goleman (1995 \& 1998), affirms that emotional intelligence is an important factor in determining competency and personal success as a student, teacher, parent, manager and leader. The differing ways of conceptualizing emotional intelligence according Petrides and Furnham (2000) that listed three main models namely hierarchical model, (cognitive) ability model, and mixed models (personality variables plus cognitive ability).

Bar On (1997) has placed emotional intelligence in the context of personality theory as an umbrella concept of noncognitive capabilities and skill to cope efficiently with environmental demands and pressures. He proposed a model of non-cognitive intelligences that includes five broad areas of skills and more specific skills that appear to contribute to success. These include intra-personal skills, inter-personal skills, adaptability, stress managemant, and general mood (optimisim happiness). 
In the recent year, the most appropriate method of measuring emotional intelligence is currently an area of controversy. Because there are many conflicting emotional model, it is not easy work to describe emotional intelligence, the proximal roots of which lie in the work of Gardner (1983) and more specifically in his concept of intrapersonal and interpersonal intelligence (Mayer, Salavey \& Caruso, 2004; Petrides, Frederickson \& Furhnam, 2004). Hence emotional intelligence is characterized by some researchers as an ability, involving the cognitive processing of emotional information, which is accordingly most appropriately measured by performances test. An alternative proposal is that emotional intelligence is a dispositional tendency like personality and can be assessed by self-assessment or self-report questionnaire.

There has been an interesting interest in the theoretical development of the concept of emotional intelligence to identify whether or not this newly introduced concept accounts for variance not already accounted for by intelligence and/or personality (Fox \& Spector, 2000; Van der Zee et al., 2002) in various human transactions. Thus, it is not currently clear if emotional intelligence actually assess the same construct, and in this context Petrides and Fruhnam (2001) have suggested the terminology 'ability EI' and 'trait EI" to distinguish the two measurement approaches. Ability EI or cognitive-emotional ability refers to one's actual ability to recognize, process and utilize emotion-laden information. Meanwhile trait EI refers to self-perceptions concerning ones' ability to recognize, process and utilize emotion-laden information. Petrides and Furhnam (2003) further stated that ability and trait EI are different construct, but then their theoretical domain and concept may overlap each other.

Recent debates on EI have focused largely on whether trait EI measured by self-report/self-assessment tests has predictive power over above traditional personality traits. The results of several studies have indicated that trait EI might be a valid construct in the prediction of life satisfaction, somatic complaints, rumination and coping styles (Kluemper, 2008; Petrides, Pita \& Kokkinaki, 2007). However, the ability of trait EI in an academic setting is still unclear (Tok \& Morali, 2009; Barchard, 2003). Consistent say that emotional intelligence as a construct has been showed to be an independent construct from personality aspect (Caruso, Mayer \& Salovey, 2002; McCrae, 2000; Zadal, 2004; Vakola, Tsaousis \& Nikolauo, 2004; Shulman \& Hemeenover,2006). They used an ability and trait to measure emotional intelligence and $16 \mathrm{PF}$ as personality measure. However, Higgs (2001) found a positive correlation between emotional intelligence and the function of Intuition, but not Feeling (Myer-Briggs Type Indicator). This findings show that the relationship between emotional intelligence and personality is still far from clear.

For the current study, the authors retained the original items for translation Malay Language. The translation work was done to suit the scale for the educator participants and more importantly, for future use in the general local population. Therefore, the definition of emotional intelligence is the same as adopted by Goleman (2001). The construct is operationally defined as the score on the EI scale developed by Goleman (2001).

\subsection{Personality Trait}

Personality is a set of psychological traits and mechanism within the individual which is organized, relatively endured and influenced a person's interaction and adaptation to the environment (Pevin \& John, 2001).

Consensus is emerging that a five-factor model of personality can be used to describe the most salient aspects of personality (Goldberg, 1990). The Big Five is the commonly used term for the model of personality which describes the five domains; extraversion, agreeableness, conscientiousness, neuroticism and openness to experience. It combines the emotion, attitude and behavior of the people. However, this study only focus on four traits; extraversion, agreeableness, conscientiousness and openness to experience.

Extroverts are often competitive in nature and highly involved in many social circles and activities. It includes traits such as sociability, assertiveness and talkativeness. Extraversion is characterized by positive feelings and experiences and its therefore seen as positive affect (Clark \& Watson, 1991). They also are often full of energy and actively seek out attention from others. For example, individuals have scoring high on this dimensions are good at getting members of the team excited about their task, increasing energy, inspiring team spirit and reducing conflict. Opposite to extraverts is introverts that may be described as quiet, reserved, shy, unsociable and like being alone (Howard \& Howar, 2004).

Openness to experiences includes active imagination, aesthetic sensitivity, attentiveness to inner feelings, a preference for variety, intellectual curiosity and independence of judgement (Nurul Hudani et al. 2012). Individuals scoring high on openness to experience are characterized by traits such as imagination, unconventionality, autonomy, creativity and divergent thinking (John \& Srivastava, 1999). They are often travelers seeking new cultures and ideas to add to their own experiences. Scoring low on the scale generally indicates people who are more straightforward or traditional.

Conscientiousness refers to self-control and involved active process of planning, organizing and caring out tasks (Barrick \& Mount, 1993). This kind of person is very responsible with work and will be very careful to make a decision. People who score high on the Conscientiousness scale show great self-discipline and awareness of their responsibility to themselves and society. They often have high regard for achievement and will use achievement as a means to measure themselves against others. This will lead to people who are very organized, academically prepared and successful in a variety of situations. They are also follow the schedules and able to accomplish tasks that they would like to do (Nurul Hudani et al. 2012).

Agreeableness is the individual who are altruistic, warm, generous, trusting and cooperative (McCrae \& Costa, 1987). In a simple way, an agreeable person is concerned with the welfare and interest of others people. Basically people who score high on the agreeableness can be a prerequisite to be able to understand others feeling as well. People who score high on the agreeableness scale show great compassion, cooperativeness and empathy for all the members of society (Nurul Hudani et al. 2012).

\subsection{Linking Emotional Intelligence and Trait Personality}

Previous research have explored the concept of emotional intelligence as the ability both to know one's own emotions and read others' emotions (Goleman, 2001). It is an important collection of a series of capabilities and abilities as the person able to maintain his motivation and resist against difficulties, postpone his impulsivities, adjust his own moods, empathy with others and hopeful (Akharzade, 2004). As the of personality is 
an abstract concept which involves actions, emotions, recognition and motivations of a person and it remained constant in a long time. Work by Zadal (2004) assessed the link between emotional intelligence using Goleman's inventory (ECI) and personality trait, reported a significant relationship between emotional intelligence and personality trait of extraversion.

Similarly, Brackett \& Mayer (2003) found significant high correlation between Emotional Quotient Inventory (Bar On's inventory) and extraversion, agreeableness, conscientiousness, neuroticism factors and moderately significant correlation were found with openness factors of the Big Five. This study was in line with the study by Sala (2002) found that the Emotional Competence Inventory (Goleman's inventory) correlated significantly with three of the Big Five Personality factors, extraversion, openness and conscientiousness. Matchimanon (2001), examined the relationship between personality and emotional intelligence of 304 employees and reported that overall emotional intelligence was significantly related to personality dimensions.Kemp, Cooper, Hermens, Gordon, Bryant \& Williams (2005) explored the relationship between Brain Resource Inventory for emotional intelligence and variables relevant to understanding on emotional intelligence. They reported that emotional intelligence was associated more with personality than with cognitive ability. It came out that the study on relationship between personality and emotional intelligence by aiming to explore what dimensions of personality strongly correlated with aspect of emotional intelligence.

The research conducted by Besharat (2010) as 'studying the relationship between the aspect of personality and emotional intelligence' found that there was a significant positive correlation between emotional intelligence, the dimensions of extraversion, managing the experiences, harmony and consciousness and negative relationship between emotional intelligence and neuroticism. The only dimensions of extraversion and neuroticism could predict the changes related to emotional intelligence in positive and negative directions, respectively. The mechanisms regulating the emotions, preparing for positive experience and preparing for negative experience justify and explain the correlation of personality dimensions and emotional intelligence (Javad et al. 2011).

Athota, O'connor \& Jackson (2009) showed in his research that emotional intelligence becomes a significant predictor of Extraversion, Openness, Agreeableness and Neuroticism. Accoding to Petrides, Vernon, Scnermer, Ligthart, Boomsma dan Veselka (2010), emotional intelligence only correlates significant positively with Extraversion, and Openness. This result was in line with those of several studies. For example, Shulman \& Hemeenover (2006) found that emotional intelligence has a positive relationship with the Extraversion and Openness domain of personality. Research on emotions in the workplace suggests that emotions may drive productivity gains, innovations, and accomplishment of individuals, teams and organizations (Cooper, 1997). Educator leaders with high emotional intelligence are said to be more effective at leading and managing others and fostering positive personality trait extraversion, agreeableness, conscientiousness and openness to experience.

\subsection{Personality \& Emotional Intelligence Performance}

Salgado (2003) argue that personality trait not only predict job satisfaction, job commitment, voluntary turnover and etc., but also affect a wide range of job performances. Several studies used dimension in personality trait to test its relationship with job performance. For example, Strang \& Kuhnert (2009) indicated that conscientiousness was consistent correlated with the job performances. This finding is in line with the results from Hofmann et al. (2005) indicates personality trait of conscientiousness associated with job performances and becomes a good predictors towards job performances (Salgado, 1997).

Whereas according to Goleman (2001) found emotional intelligence is positively related to job performance. The study done in Malaysia by Rohana, Kamaruzaman \& Zanariah (2009) reported that EI is positively related to work-attitude including appraisal and expression of emotion are moderately correlated to job performance and job satisfaction. Therefore, in order for examining the whole productivity of the ones organization, measuring the performance of a leader is of paramount importance to the persons and organizations. Improving each leader's performance and developing the individual and team's potential can be measured by assessing their personality trait and emotional competence. In short, the relationship between personality and emotional intelligence are considered one of the most popular areas in developing human potential effectiveness.

\subsection{Leadership Behavior}

Leadership can be defined as the process where, upon contact, humans influences each other's behavior (Nordin et al. 2001). There are two types of leadership behavior have been using in this study; transformational and transactional leadership among the educator leaders in schools.

\subsection{Transformational Leadership}

The transformational leadership focuses on what the leader accomplishes rather than on the leader's personel interest and his relationship with group members. Dubrin (2007) reports that transformational leadership focuses on a leader's understanding to bring about major, positive changes by moving group members beyond his self-interest and toward the good of the group, organization or society. The essence of transformational leadership is developing by motivating, inspiring, encourage subordinates to be more creative and generate new ideas on how to solve problem or develop new ways to achieve the goals. The transformational leadership can be subdivide into four factors; idealized influences or charisma, inspirational motivation, individual consideration and intellectual stimulation.

\subsection{Transactional Leadership}

Recently, transactional leadership is often used by many companies. According to Dubrin (2007) define transactional leaders focuses on more routine transactions rewarding group members for meeting standards (contingent reinforcement). It is the pattern of leadership prevalent in most organization because it contains a basic mechanism of exchange relationship which becomes possible when there is no outstanding sense of impending threat or anxiety. The concept of transactional leadership is narrow in that it does not take the entire situation or future of the organization in mind when offering rewards 
(Crosby, 1996). According to Clawson (2005) and Judge \& Bono (2000) transactional leadership has four characteristic namely contingent reward, passive management by exception, active management by exception and laissez-faire.

\subsection{Work Performance}

Benefits are deeply concerned by all organizations, while organizational benefits depend on individual work performance. It is the critical factor in developing the effectiveness and success of any organization. Thus work performance should be paid more attention. Job performance is a multi-dimensional construct which indicates how well employees perform their task tasks, the initiative they take and the resourcefulness they show in organizing planning (Rothman \& Coetzer, 2003). According to Campell, McCloy, Oppler \& Sager (1993) work performance is an actions or behaviour that are relevant to the organization's goal and that can be scaled (measured) in terms of each individual's proficiency.

Job performance could be affected by situational factors, such as the characteristic of the job, the organization, coworkers and by dispositional factors. According to House, Shane \& Herrold (1996) dispositional variables can be described as personality characteristic, needs attitudes, preferences and motives that result in a tendency to react to situations in a predetermined manner. Therefore, performance is widely agreed to be multi faceted concept (Suliman, 2001). Somers and Birbaum (1998) suggest that using multiple dimensional scales to study performances relationship with other variables is necessary to examine and understand the nature, significance and strength of these relationship.

\subsection{METHOD}

\subsection{Research Design}

The authors opted for a cross-sectional design. This study chooses survey techniques and questionnaires to collect the data and conducted in the natural environment of the organization.

\subsection{Sample Procedure}

Sample procedure refers to process of selecting individuals from the target population. The sampling frame for the study was acquired from 15 High Performance Schools (SBT) in Malaysia based on five selected location (Zone North, East, South, Middle, Sabah/Sarawak). Then, the sample was chosen by using purposive design that involved such as principals, senior assistant 1 , senior assistant 2, Co-Curriculum of senior assistant, head of programme and also head of core- subject.

\subsection{Procedure of Research}

Before the study began, ethical approval was first obtained from the Education Planning And Research Division (EPRD), Boarding School Management \& School Excellence Division, Ministry of Education Malaysia (KPM) and State Education Department. Upon this official clearance, initial verbal contact was then made to the selected SBT schools authorities to explain the intention of the study. This process was later followed by an official letter of application plus the approval from the Ministry of Education. Upon receiving the official approval from each school, a further verbal discussion through telephone was made. The aim was to arrange the date and time of the days suitable for meeting the subjects.

\subsection{Instruments}

The questionnaire pack comprises sections that measures demographic information, emotional intelligence, personality trait, leadership behaviour and work performances. All parts of the questionnaire have both English and Malay Language versions. Back translation method was used to ensure the accuracy of the translation. As for demographic, the respondents were required to answer questions about their age, sex, race, religion, marital status and experiences as leaders in school.

The Emotional Intelligence Scale consists of 63 items for measuring global emotional intelligence. To asses leadership behavior, the questionnaire comprised 32 item adopted from Multifactor Leadership Questionnaire (MLQ5X) whereas for NEO Five factor inventory, a 48 item version of the NEO PI-R was used to examine personality trait; Extraversion, Openness to Experience Agreeableness and Conscientiousness. Work Performances Inventory, a 22 item scale for measuring job performances and the respondent were asked to express their opinion on the likert scale point.

\subsection{Data Collection \& Statistical Analysis}

There were $321(93.5 \%)$ respondents who completed the study. But only $306(89.2 \%)$ questionnaires were included in the analysis after screening process was done.The data were analyzed using SPSS for Windows 16.0 and Analysis of Moment Structures (AMOS) 18. Internal consistency was used as the reliability estimate for all scales. For this purpose, $\alpha-$ Cronbach was calculated and presented in Table 1. For the criteria validity, inter- item correlation was conducted by using Pearson, it was indicates sowing score MLQ5x range from .504 to .639 , ECI range from 0.532 to 0.707 , NEO-PI-R range from 0.571 to 0.721 and work performance range from 0.516 to 0.714 .

Table 1 Internal reliability ( $\alpha$-Cronbach) of the scales

\begin{tabular}{lc}
\hline Measures & a-Cronbach \\
\hline Emotional Intelligence Scale & .970 \\
Five Factor Model Personality & .869 \\
Multifactor Leadership Questionnaire & .917 \\
Work Performance Inventory & .919 \\
\hline
\end{tabular}

\subsection{FINDING AND DISCUSSION}

Table 2 presents the relationship between the dimensions of the Five Factor Model of Personality and emotional intelligence. The matrix technique of Pearson Correlation was used to measure the relationship.

H 1 There is a positive significant relationship between personality trait. 
Table 2 Pearson correlation between the five factor model of personality and emotional intelligence

\begin{tabular}{lc}
\hline Dimensions of Personality & Emotional Intelligence \\
\hline Extraversion & $0.505(* *)$ \\
Agreeableness & $0.193(* *)$ \\
Openness To Experience & $0.362(* *)$ \\
Conscientiousness & $0.552(* *)$
\end{tabular}

$\mathrm{N}=306$

** Correlation is significant at the 0.01 level (2-tailed)

*Correlation is significant at the 0.05 level (2-tailed).

4.1 Correlation Matrix of the Relationship Between Personality Trait and Emotional Intelligence

The result analysis in Table 2 shows that there is a significant positive relationshipbetweenConscientiousness $(\mathrm{r}=.552, \mathrm{p}<.05)$, Openness to experiences $(\mathrm{r}=.362, \mathrm{p}<.05)$, Extraversion $(\mathrm{r}=.505$, $\mathrm{p}<.05)$, Agreeableness $(\mathrm{r}=.193, \mathrm{p}<.05)$ and Emotional Intelligence. Consequently, hypothesis $\mathrm{H} 1$ is accepted.

Given the significance of the positive relationship between Conscientiousness, Openness to experiences, Extraversion, Agreeableness and emotional intelligence. This study shows that human traits of personality Conscientiousness, Openness to experiences, Extraversion and Agreeableness is more likely to engage in emotional intelligence in schools institution e.g. the higher the respondents' level of emotional intelligence, the more extraverted he or she is and same goes to the other trait. Finding from a study conducted by Skovholt \& D'Rozario (2000) suggest that excellent teachers are those who display empathy toward other and have ability to interact socially with their environment. Moreover, school leaders with high emotional intelligence excel in their job because they are always open to new ideas and welcome any feedback about any issue from others includes colleagues and students. This will open a communication pathway as well as preserve future changes.

As for correlation analysis, emotional intelligence correlated with all dimension of personality such as Conscientiousness, Openness to experiences, Extraversion, dan Agreeableness. This means the subjects was affected by the personality traits and emotional intelligence. People high in EI are more tough minded, more emotionally stable, and outward oriented. This indicates that emotional intelligence goes hand in hand with other positive personality traits. Indeed, it was supported by other researchers such as McCrae (2000), Day \& Carrol (2004), Zadel (2004), Shulman \& Hemeenover (2006) and Athota, O'connor \& Jackson (2009) reporting a similar set of findings.

The results also suggest the particular measure of EI (Goleman, 2001) reflects emotional intelligence as a trait. This is in contrast with findings by Caruso et al. (2002) where EI is found to be an independent construct from personality. It is possible that the independence is observed because Caruso et al. used an ability based measure of EI. On the other hand, in a discriminant validity study conducted by Schutte et al. (1998), their EI measure did not correlate with the big five personality measures except for openness to experience. Nevertheless, the validation study was conducted on 23 college students whose average age is lower than the present sample. The results obtained by Schutte et al. (1998) could have been obtained due to the narrow range of data. Therefore, we might still conclude that the connection between personality and emotional intelligence depends on the type of measure used.
In this study, the strongest correlation is observed for Conscientiousness. The result of our study, along with those of previous studies, clearly indicate the useful nature of the personality trait, especially Conscientiousness. The higher the respondents' level of emotional intelligence, the more Conscientiousness he or she is. This was consistent with the study was done by Douglas \& Frink (2004) indicated that person has a high level of emotional intelligence brings a positive effects on Conscientiousness trait personality. According to Ones and Viswesvaran (1996) have suggested a theory of conscientiousness at work, according to which highly conscientious individuals show greater self-control, organizing, strong-willed and careful than less conscientious individuals because: (a) they spend more time on orderliness(s) they are assigned to; (b) they acquire greater job knowledge; (c) they set goals autonomously and persist in following them; (d) they go beyond role requirement in the workplace; and (e) the avoid counterproductive behavior. Thus, conscientious individuals are better educator leaders than less conscientious people because they control their work-related behaviors as well as their emotional status.

For the individuals with high character of conscientiousness, they would live their education with goals, circumspectness, unwaveringness, punctuality and reliability. It was concluded that educators leaders with high conscientiousness and high emotional intelligence would always perceive self confident, self worthiness, motivated to work for targets sets, concentrated at work and recognition of problem solving approach even though in the changing proses. These characters are necessary for working in a school institution. Moreover, Salgoda (1997) found that conscientiousness and emotional stability were predictor in predicting job performance. In comparison with the theory, the current study also produced a similar finding that high conscientiousness individual does show greater emotional level of intelligence with a score of $r=.552, \mathrm{p}<0.05$. Therefore it is to say, the more conscientious an individual is in the school organization, the more emotional on part of the production positive feeling dimension has occurred.

4.2 Result of Analysis of Model fitness by SEM (Structural Equation Modeling) for Emotional Intelligence, Personality Trait, Leadership Behavior and Work Performance

Several goodness-of-fit indices are commonly used to evaluate how well the structural model fits the data. The chi square goodness-of-fit test is one of the most commonly used indices. However the most popular of alternatives measures model fit indices includes such as TLI (Tucker-Lewis Index), NFI (Normed Fit Index), RFI (Relative Fit Index), IFI (Incremental Fit Index) and CFI (Comparative Fit Index) values ranging from 0 to 1 ; a good fit is indicates by greater than .90 . Regarding to RMSEA (Root Mean Square Error of Approximation) indicates a small RMSEA and a very narrow confidence interval suggest good precision of the RMSEA in reflecting model fit in the population and a non significant $\mathrm{Chi}$ Square Goodness of Fit (CMIN) should be refer too. Table 3 presents the measurement model of fitness before modification by using analysis of SEM.

H 2 There is a suitable fitness of the suggestion model for Emotional Intelligence, Personality Trait, Leadership Behavior and Work Performance 
Table 3 Measurement model of fitness before modification

\begin{tabular}{ll}
\hline Measurement of fitness & Index \\
\hline i. Absolute Fit Index (AFI) & 209.186 \\
Chi Squared Roots (X2) & 59 \\
Degree of freedom (df) & .000 \\
Significant level for Chi-Squared Roots, p(>.05) & \\
& \\
ii. Incremental Fit Index (IFI) & .939 \\
Tucker-Lewis Index (TLI), (>=.90) & .938 \\
$\quad$ Normed Fit Index (NFI), (>=.90) & .917 \\
Relative Fit Index (RFI), (>=.90) & .954 \\
Incremental Fit Index (IFI), (>=.90) & .954 \\
Comparative Fit Index (CFI), & .091 \\
& \\
iii. Root Mean Square Error of Approximation & \\
(RMSEA) & .709 \\
& \\
iv. Parsimony Fit Index (PFI) & 273.186 \\
Parsimon Norma Fit Index (PNFI) & \\
Akaike Information Criteria (AIC) & \\
\hline
\end{tabular}

The result analysis in Table 3 shows that all the model fit indices such as TLI (Tucker-Lewis Index), NFI (Norm Fit Index), RFI (Relative Fit Index), IFI (Incremental Fit Index) and CFI (Comparative Fit Index), RFI (Relative Fit Index), IFI (Incremental Fit Index) and CFI (Comparative Fit Index) indicates greater than .90 (from .917 until .954). A good fit is indicated by values greater than .90 . is an adequate fit between hypothetical model and the sample data. Thus, it can be concluded that there is a relatively good fit between the model and the data. Figure 2 shows suggestion hypothesis model before modification.

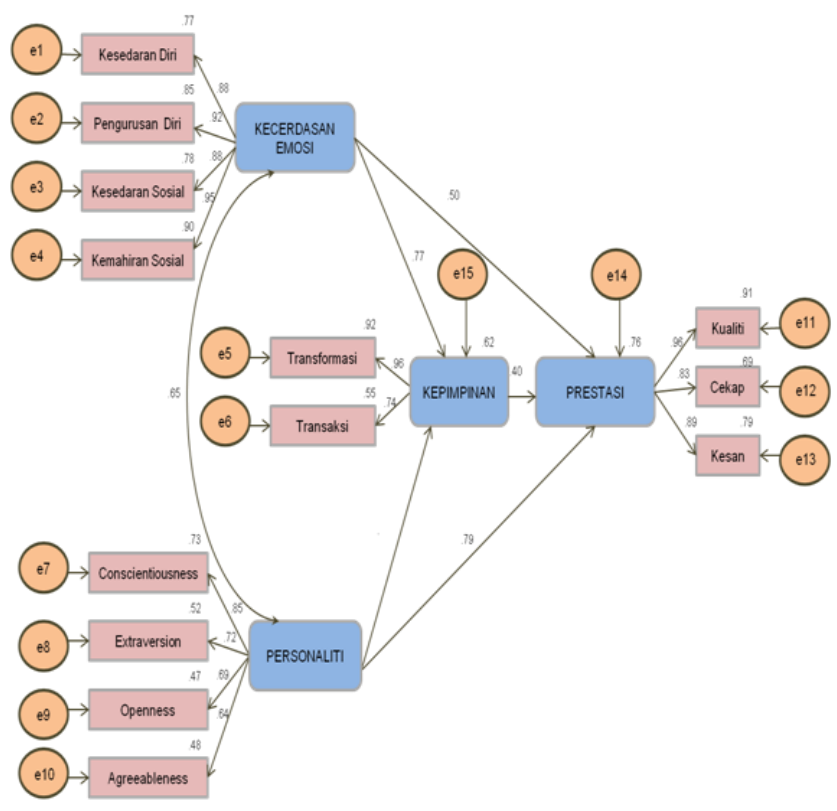

Figure 2 Suggestion hypothesis model before modification

However based on Table 3, it shows contrasting findings of RMSEA ((Root Mean Square Error of Approximation) which indicates $.91 \quad(<.08)$. In fact, it also consistent with the Chi Square value of 209.186 is significant $[\mathrm{X} 2(\mathrm{~N}=306, \mathrm{df}=59)=$ 209.186, $p<.05]$. As mentioned, given the known problem of
Chi Square test in SEM, it is more beneficial to use alternative indices. Therefore, this study indicates that significantly suggested hypothesis model is not suitable with the sample data.

Therefore, in this study, researcher perform modification to develop a better-fitting model based on the modification indices. This mean, a model can be modified by eliminating existing path and /or specifying new paths. Figure 3 shows the research model after modification by using AMOS programme. Based on Table 4, result shows that Chi-Square value is significant $[\mathrm{X} 2(\mathrm{~N}=306, \mathrm{df}=49)=95.016, p<.05]$. In this case, the Chi-Square values has been changes from 209.186 to 95.016 after the original model was modified. Indeed, model fit indices demonstrated TLI (Tucker-Lewis Index), NFI (Normed Fit Index), RFI (Relative Fit Index), IFI (Incremental Fit Index) and CFI (Comparative Fit Index) values are more greater than .90 (from .955 until .986). Based on Baseline Comparisons, the fitness value greater than .90 indicates that suggestion model significantly is more suitable with the sample data. Besides, these values are also higher than the original model. Thus, modification model is significantly more fit with the sampel data compared to the original model was proposed by researcher. Consistent with the value of RMSEA (Root Mean Square Error of Approximation) also shows .055 (RMSEA <.06) indicates met the basic requirement of model fit indices.Based on the modification indices, the model fit can be improvement by correlating several variables in order to obtain the suitable fitness with the sample data. The AMOS also allows the use of modification indices to improve the model fit by drawing a correlation function between the identified variables (WL Cheah et al. 2010). However, the model modification is used to generate new models, it is critical that the decision be based on theoretical issues and not based solely on guidance from empirical indices. Furthermore, modification indices will determine whether additional paths can be added to the existed model.

Table 4 Measurement model of fitness after modification

\begin{tabular}{ll}
\hline Measurement of fitness & Index \\
\hline i. Absolute Fit Index (AFI) & \\
Chi Squared Roots (X2) & 95.016 \\
Degree of freedom (df) & 49 \\
Significant level for Chi-Squared Roots, p(>.05) & .000 \\
& \\
ii. Incremental Fit Index (IFI) & .978 \\
Tucker-Lewis Index (TLI), (>=.90) & .972 \\
$\quad$ Normed Fit Index (NFI), (>=.90) & .955 \\
Relative Fit Index (RFI), (>=.90) & .986 \\
Incremental Fit Index (IFI), (>=.90) & .986 \\
Comparative Fit Index (CFI), & .055 \\
& \\
iii. Root Mean Square Error of Approximation & \\
(RMSEA) & .610 \\
iv. Parsimony Fit Index (PFI) & 179.016 \\
Parsimon Norma Fit Index (PNFI) & \\
Akaike Information Criteria (AIC) &
\end{tabular}




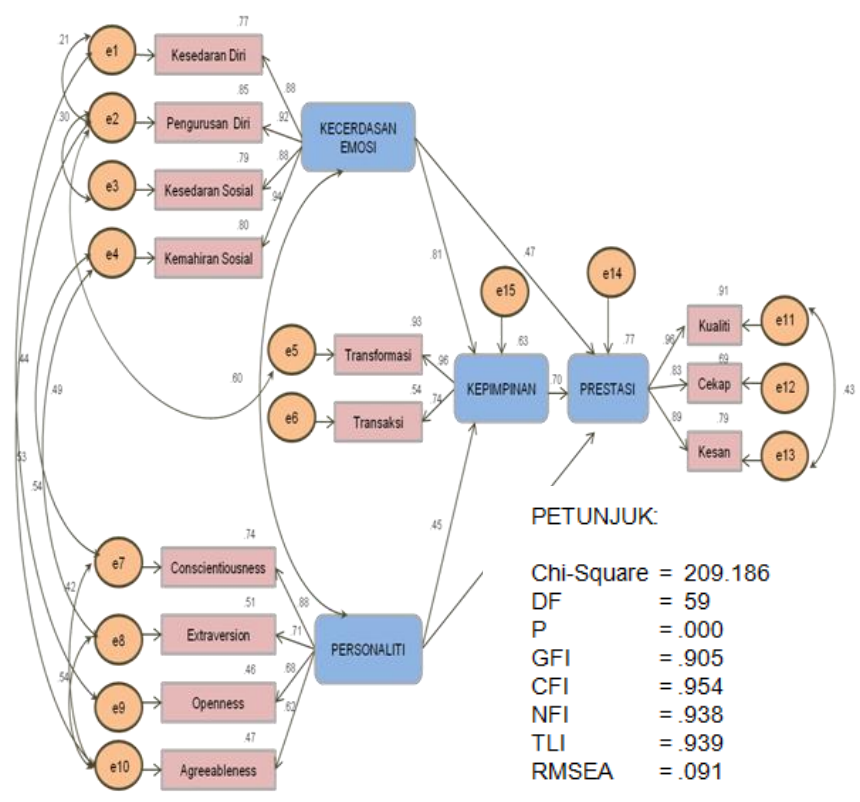

Figure 3 Suggestion hypothesis model after modification

In this study, the modification indexes suggested such the relationship are between e 4 and e7, e 1 and e9, e 4 and e 8 and etc. as shown in figure 2 as it was supported by theoretical reasons. The re-estimate this re-specified model based on these changes, the TLI, NFI, RFI, IFI and CFI would improve and the model would be reasonably good fit to the data. This was done because if followed modification indexes suggested such the relationship are between e 4 and e7, e 1 and e9, e 4 and e 8 and etc as shown in figure 2 as it was supported by theoretical reasons. The reestimate this re-specified model based on these changes, the TLI, NFI, RFI, IFI and CFI would improve and the model would be reasonably good fit to the data. This was done because if followed the modification indices suggestion, then the values of Chi-square roots Goodness Fit will be reduce and made the model is more fit and suitable with the data as well as it make theoretical sense for the model. This results was consistent with the study of oleh Sala (2004), Murensky (2000), Vakola, Tsaousis \& Nikolauo (2004) dan Petridez, Perez- Gonzalez \& Furhnam (200\&).

The SEM model specification of the relationship between the variables is based on a combination of various theories (Goleman theory, Big five personality trait, transformational leadership) and empirical results from other previous research and studies. The researcher's selection of the variables and pathways represented in the model binds the SEM model's potential to regenerate the sample covariance and variance pattern (Hoyle, 1995). As such, in spite of this study 's SEM model being verified as a good fit for the data analysis purposes, there may be several alternative models that may be fit the data equally well. In light of this study, the combination of all variables can be a good example to be pooled together as a perfect combination to ensure overall significant improves toward job performances.

Once again, given different perspective or orientation in terms of valid path diagram representing the relationship between variables, an alternative model that can be in fact reexpress the data perfectly may be identified. Therefore, the research on conceptual framework can be enriched in terms of identifying a SEM model that can fit the data well enough to enable the researcher to examine and analyze the work performance phenomena under observation as well.

\subsection{IMPLICATION}

The finding support the nation that personality trait, leadership and emotional intelligence will improve the leader performance. This study supports that personality, leadership and emotional intelligence at the organizational level is a prerequisite for successful organizational change to improve performance. For example, it implies that organization should provide an adequate conducive environment and training of EI for leaders. Emphasizing more training in emotional intelligence would help leaders to be more open in expressing their emotions thus will help them to manage their emotions to enhance their performance as well as adjust their personality consistently and leadership behavior. As for the suggestion model, it indicates that the model fit the data after modification implies that emotion intelligence, personality trait, leadership behavior need to be pooled together to ensure an overall significant on competitive change and performance. This enables leaders to prioritize their work activity accordingly with respect to their potential as far as the objective and organization target. Nonetheless, the conceptual framework of this research provides leaders with a practical organizational model that can be utilized to assess and understand the internal strengths and weaknesses to improve the level of individual performance.

\subsection{CONCLUSION}

This study investigated the relationship among the emotional intelligence and personality trait conscientiousness, openness to experiences, extraversion and agreeableness. The research examined the strength of relationship from educator leaders' perspective. Overall, the result of this study show that conscientiousness, openness to experiences, extraversion, agreeableness and emotional intelligence are useful in relationship of leadership behaviour in schools context.The finding revealed that conscientiousness emerged as stonger relationship of emotional intelligence followed by extraversion, openness to experiences, and agreeableness. This current study provide preliminary evidence for the relationship between personality trait, emotional intelligence, leadership behaviour and job performance as the result indicates the fitness of the model suggestion.

\section{Acknowledgements}

The author wishes to express sincere appreciation to the Universiti Putra Malaysia, Universiti Malaysia Sabah, all educator leader in SBT for their extended long-term support and especially to supervisor Dr Marof Redzuan for his vast reserve of patience and knowledge. This articles would never have been completed without the encouragement and devotion of my family and friends.

\section{References}

Bar-On, R. 1997. The Emotional Quotient Inventory (EQ-i): Technical manual. Toronto: Multi Health Systems.

Bar-On, R. 2000. Emotional and social intelligence: Insights from the emotional quotient inventory. In R. Bar-On \& J.D.A. Parker (Eds.). The 
Handbook of Emotional Intelligence: Theory, Development, Assessment \& Application at Home, School and in the Work Place: San Francisco: Jossey-Bass. 363-388.

Beshart, Muhammad Ali (2010). The Relationship Between Emotional Intelligence And Self-Efficacy And Academic Succes. Education Renovation Journal. 2(910): 1-10

Burns, J. M. 1978. Leadership. New York: Harper \& Row.

Caruso, D., Mayer, J. D., \& Salovey, P. 2002. Emotional intelligence and emotional leadership. In R.Riggo \& S. Murphy \& F.J. Pirozzolo (Eds.). Multiple Intelligence and Leadership. Mahwah, NJ :Lawrence Erlbaum.

Costa, P. T. \& McCrae, R. R. 1988. Personality In Adulthood: A Six-Year Longitudinal Study of Self-Reports and Spouse Ratings on the NEO Personality Inventory. Journal of Personality and Social Psychology. 54: 853-863.

Costa, P. T., \& McCrae, R. R. 1989. NEO PI-R professional manual. Odessa. F1: Psychological Assessment Resources Inc.

Costa, P. T \& Mc Crae, R. R. 1992. Revised NEO Personality Inventory (NEO-PI-R) and NEO Five Factor Inventory (NEO-FFI) Profesional Manual. Odesse,Fc;Psychological Assessment Resources. Inc.

Costa, P. T., Terracciano, A., \& McCrae, R. 2001. Gender Differences in Personality Traits Across Cultures: Robust and Surprising Findings. Journal of Personality and Social Psychology. 81(2): 322-331.

Dulewicz, V. \& Higgs. M. 1999. Can emotional Intelligence be Measured and Developed? Leadership and organizational Development Journal. 20(5): 242-253.

Gardner, H. 1983. Frames of Mind: The Theory of Multiple Intelligence. New York: Basic Books.

Goldberg, L. R. 1990.An Alternative Description of Personality-The Big Five Factor Structure. Journal of Personality and Social Psychology. 59(6): 1216-1229

Goleman, D. 1995. Emotional Intelligence: Why It Can Matter More Than $I Q$. New York: Bantam Book.

Goleman, D. 1998. Working with Emotional Intelligence. New York : Bantam Book.

Goleman, D. 2000. Leadership that Gets Results. Harvard Business Review. $78-90$

Goleman, D. 2001. An EI-based Theory of Performance. In C.Cherniss \& D. Goleman (Eds.) The Emotional Intelligence Workplace. San Francisco: Jossey- Bass.
Higgs, M. 2001. Is There a Relationship between Myers-Briggs Type Indicator (MBTI) and Emotional Intelligence? Journal of Managerial Psychology. 16(7): 509-533.

Huffman, K. 2007. Psychology in Action. USA: John and Wiley.

Judge,T. \& Bono, J. E. 2000. Relationship of Core Self-Evaluation with Job Satisfaction and Job Performances: A Meta-analysis. Journal of Applied Psychology. 86(1): 80-92.

Mayer, J. D., Salovey, P., \& Caruso, D. R. 2000. Emotional Intelligence as Zeitgeist, as Personality and as a Mental Ability. In R.Bar-On and J. Parker (Eds). The Handbook of Emotional Intelligence: Theory, Development, Assessment and Application At Home, School and in the Workplace. San Francisco, California: Josey-Bass Inc. 92-117

Mayer, J. D., Salovey, P., \& Caruso, D. R. 2004. Emotional intelligence: Theory, Findings and Implications. Psychological Inquiry. 15: 197-215.

Petrides, K.V., Frederickson, N., \& Furhnam, A. 2004. The Role of Trait Emotional Intelligence in Academic Performance and Deviant Behavior At School. Personality and Individual differences. 36: 163-172.

Petrides, K.V \& Furhnam, A. 2004. Trait Emotional Intelligence: Behavioural Validation in Two Studies of Emotion Recognition and Reactivity to Mood Induction. European Journal of Personality. 17: 39 57.

Rohana Ngah, Kamaruzaman Jussoff, \& Zanariah Abdul Rahman. 2009. Emotional intelligence of Malaysia academia towards work performances, International Education Studies. 2(2): 103-112.

Salovey. P \& Mayer, J. D. 1990. Emotional Intelligence. Imagination, Cognition and Personality. 9: 259.

Shulman, E. T., \& Hemenover, S. H. 2006. Is Dispositional Emotional Intelligence Synonymous with Personality? Self and Identity. 5: 147171

Vakola, M., Tsaousis, I., Nikolaou, I. 2004. The Role of Emotion Intelligence and Personality Variables on Attitudes Towards Organizational Change. Journal of Managerial Psychology. 19(2): 88-110.

Zadel, A. 2004. Impact of Personality Andemotional Intelligence on Successful Training in Competences. Managing Global Transitions. 4(4): $363-376$ 